\title{
An epidemiological survey of Dirofilaria spp. and Acanthocheilonema spp. in dogs from the Republic of Moldova
}

\author{
Mirabela Oana Dumitrache ${ }^{1}$, Gianluca D'Amico ${ }^{*}$ (D), Eugeniu Voinițchi ${ }^{2}$, Serghei Maximenco ${ }^{4}$,
} Viorica Mircean ${ }^{1}$ and Angela Monica Ionică ${ }^{1,3}$

\begin{abstract}
Background: During the last decades, filarial infections caused by Dirofilaria spp. have spread rapidly within dog populations of several European countries. Increasing scientific interest in filariasis, and the availability of new diagnostic tools, has led to improved knowledge of the biology, morphology, and epidemiology of different species of filarial worms. However, data are still scarce for a number of countries, including the Republic of Moldova. Thus, we assessed the epidemiological status of canine filariasis in the Republic of Moldova to address part of this knowledge gap.

Methods: A total of 120 blood samples were collected between June 2018 and July 2019 from dogs originating from the cities of Cahul and Chişinău. The samples were examined microscopically, and multiplex polymerase chain reaction was performed to evaluate filarioid species diversity.

Results: Microscopic examination revealed that 12 dogs (10.0\%) were positive for circulating microfilariae. The molecular test showed that one dog was positive for Acanthocheilonema reconditum (0.8\%), one for Dirofilaria immitis (0.8\%), six for Dirofilaria repens (5.0\%), and four (3.3\%) harboured a co-infection with D. immitis and D. repens. Prevalence was significantly higher in dogs aged $\geq 2$ years.

Conclusions: The epidemiological survey presented here for the Republic of Moldova confirmed the presence $D$. immitis, D. repens and A. reconditum in dogs that had not received any heartworm preventive.
\end{abstract}

Keywords: Dirofilaria, Acanthocheilonema, Vector-borne disease, Zoonosis, Dog, Republic of Moldova

\section{Background}

Filarioids (superfamily Filarioidea) are vector-borne nematodes that pose a health risk to both domestic and wild animals and to humans [1]. Numerous filarial species have been identified and characterized by morphological and molecular methods during the last decades [2-4]. Moreover, the evolution of existing diagnostic

\footnotetext{
*Correspondence: gianluca.damico@usamvcluj.ro

${ }^{1}$ Department of Parasitology and Parasitic Diseases, University

of Agricultural Sciences and Veterinary Medicine Cluj-Napoca, 3-5 Mănăştur Street, 400372 Cluj-Napoca, Romania

Full list of author information is available at the end of the article
}

tools and the availability of new ones have enabled an increase in our knowledge of the epidemiology and ecology of many filarial species [1]. Although some species have been intensively studied, and awareness of filarioid infections for various mammals is high (e.g. infections with Dirofilaria immitis and Dirofilaria repens), other filarial species have been rather neglected (e.g. Cercopithifilaria bainae and Cercopithifilaria grassii) or are less well known (e.g. Acanthocheilonema reconditum, Acanthocheilonema dracunculoides and Onchocerca lupi) [4].

Dirofilariasis is one of the most studied and best-known parasitic diseases. It is caused by 
mosquito-borne nematodes, of which $D$. immitis and $D$. repens are the most important $[4,5]$ due to their high pathogenicity, potential negative impact on public health, wide distribution and endemicity [5]. Both $D$. immitis and D. repens can be transmitted by several genera of culicid vector (Anopheles, Aedes, Ochlerotatus, Culex, Culiseta and Coquillettidia) [6]. D. immitis may cause a severe cardiopulmonary condition in dogs and other domestic, and wild, carnivores [5]. Although humans are considered to be accidental hosts, infections occasionally occur and can cause pulmonary conditions and, in some instances, ocular or subcutaneous diseases [7-9]. D. repens is the agent of subcutaneous dirofilariasis in animals, which usually has a mild clinical manifestation or is unrecognised. However, various skin lesions may occur, such as non-inflammatory nodules, circular alopecia, localised erythema, and lichenification and hyperpigmentation of affected areas in chronic cases. Depending on their localization and immune reactions, these lesions may be pruritic or painful, but are usually neither [10]. D. repens is the main agent of dirofilariasis in humans, in whom it most frequently causes ocular and subcutaneous diseases. Other localisations (e.g. pulmonary, oral cavity, eyelid) of the disease have also been reported [9]. In Europe, $D$. repens is recognised as an emergent pathogen. Microfilariaemic dogs represent the main reservoir for animal and human infections with $D$. immitis and D. repens [10]. A northeastern multifactorial spread (due to influences such as climate change, vector availability, dog and human circulation, etc.) of both $D$. immitis and $D$. repens in areas previously considered non-endemic for dirofilariasis has been recently observed [4]. These two species, as well as Thelazia callipaeda, another vectorborne pathogen of dogs, are considered key examples for this pattern of emerging parasitic disease [4]. Thus, epidemiological studies in areas where no or limited information is available on them, but where they are expected to be present, are essential.

Another filarioid species that parasitises dogs, and has been reported once in a human patient [11], is $A$. reconditum. Although this species is the most widely spread filarial worm and has a global distribution, it is one of the less pathogenic filarioids in dogs, and its low clinical impact has been previously demonstrated $[4,12]$. However, this parasite, which is mainly found beneath the subcutaneous tissues of the limbs and dorsal region of dogs, might be responsible for alopecia and/or dermatitis in the same areas $[4,12]$. The life cycle of $A$. reconditum, unlike that of any other filarioid, depends on several species of fleas (Ctenocephalides canis, Ctenocephalides felis, Pulex irritans, Pulex simulans, and Echidnophaga gallinacea) or lice (Linognathus setosus and Heterodoxus spiniger), which serve as vectors and intermediate hosts [4].

Several methods are used for the diagnosis of filarial infections, such as microscopic detection of circulating microfilariae, a commercial test designed to detect the presence of blood antigens released by adult females of $D$. immitis, and molecular-based methods such as polymerase change reaction (PCR) and duplex real-time PCR [6, 13]. Echocardiography is also used for the diagnosis of $D$. immitis in dogs [4].

Even though the veterinary significance of $D$. immitis, $D$. repens and $A$. reconditum has been acknowledged [4, 5], there are still some gaps in knowledge regarding their epidemiology and biology. Two recent epidemiological studies suggested the presence and the circulation of Dirofilaria spp. in humans [14] and in arthropod vectors [15] in the Republic of Moldova, but a correlation analysis between the prevalence and geographical distribution of these nematodes in canine and human populations could not be carried out due to the lack of epidemiological studies on dogs. To address this lack, our study assessed the prevalence of canine filariasis in dog populations in the Republic of Moldova and the associated risk factors.

\section{Methods \\ Sampling}

Convenience sampling of 120 dogs was performed between June 2018 and July 2019. The dogs originated from public dog shelters located in the south (Cahul, $n=42$ ) and central (Chișinău, $n=48$ ) parts of the country, and from veterinary clinics in Chişinău $(n=30)$. All the shelter dogs were housed outdoors, while the owned dogs had a mixed lifestyle. Only owned animals that did not receive any kind of preventive treatment for dirofilariasis were included in the study. We assumed that the dogs from the shelters had not received any kind of chemoprophylactic treatment against filarial infections. Informed consent was obtained from the dog owners and managers of the shelters before the inclusion of the dogs in the study.

Blood samples were collected from the cephalic vein of each $\operatorname{dog}(2 \mathrm{ml})$ and stored in a labelled tube with anticoagulant (ethylenediaminetetraacetic acid). Location, sex, age, breed, origin and travel history were recorded for each dog, to assess the risk factors for Dirofilaria spp. and $A$. reconditum infections.

\section{Microscopic examination}

For each dog, $1 \mathrm{ml}$ of blood was processed by the modified Knott's test according to the standard procedure [16]. The sediments were examined using an Olympus BX61 microscope. Microfilariae were identified based on their 
morphology [16]. Photographs and measurements for morphological identification were obtained using a DP72 camera and Cell ${ }^{\wedge} \mathrm{F}$ software (Olympus, Tokyo, Japan).

\section{Molecular analysis}

Genomic DNA was extracted from $200 \mu$ of whole blood using a commercial kit (Isolate II Genomic DNA Kit; Bioline, London) according to the manufacturer's instructions. Multiplex PCRs amplifying partial regions of the cytochrome c oxidase subunit 1 gene of three filarioid species [D. immitis, 169 base pairs (bp); D. repens, $479 \mathrm{bp}$; and $A$. reconditum, $589 \mathrm{bp}$ ] were performed using species-specific forward primers and the reverse primer NTR, as described in the literature [17]. The PCR products were visualized by electrophoresis in a $2 \%$ agarose gel stained with RedSafe $20,000 \times$ Nucleic Acid Staining Solution (Chembio, Hertfordshire, UK), and their molecular weights determined by comparison to a molecular marker (HyperLadder 100bp; Bioline). All the corresponding bands were excised from the gel and purified using a commercially available kit (Isolate II PCR and Gel Kit; Bioline). The purified products were sequenced by an external service (Macrogen Europe, Amsterdam). The obtained sequences were compared to those available in GenBank by a Basic Local Alignment Search Tool (BLAST) analysis.

\section{Statistical analysis}

Data analysis was performed using Epi Info 7 software (Centers for Disease Control and Prevention, USA). The frequency and prevalence of infection are reported with 95\% confidence intervals (CIs), and the risk factors (locations, sex, age, breed, and origin of the animals) were assessed using a Chi-square test. Differences were considered statistically significant at $P<0.05$.

\section{Results}

Microscopic examination revealed that 12 dogs (10.0\%; 95\% CI 5.3-16.8) were positive for circulating microfilariae. Age had a significant effect on filarioid infection, as all of these dogs were $\geq 2$ years old (Chi-square test, $\chi^{2}=2.91, d f=1, P=0.038$ ). There were no significant differences regarding location, sex, breed or origin of the animals (Table 1).

Among the microfilariaemic dogs, one was positive for Acanthocheilonema sp. (0.8\%; 95\% CI 0.0-4. 6), one for D. immitis (0.8\%; 95\% CI 0.0-4.6), six for D. repens (5.0\%; 95\% CI 1.9-10.6), and four (3.3\%; 95\% CI 0.9-8.3) harboured a co-infection with D. immitis and D. repens. Infection with Acanthocheilonema spp. was identified only in Cahul, while Dirofilaria spp. were detected at both locations. Although prevalence tended to be higher for both Dirofilaria spp. in Cahul than in Chişinău, the
Table 1 Prevalence of filarioid infections (regardless of species) in sampled dogs from the Republic of Moldova

\begin{tabular}{|c|c|c|c|c|c|}
\hline Variables & Frequency & Prevalence & $95 \% \mathrm{Cl}$ & $x^{2}(d f)$ & $P$-value \\
\hline \multicolumn{6}{|l|}{ Location } \\
\hline Chișinău & $7 / 78$ & $9.0 \%$ & $3.7-17.6$ & $0.036(1)$ & 0.751 \\
\hline Cahul & $5 / 42$ & $11.9 \%$ & $4.0-25.6$ & & \\
\hline \multicolumn{6}{|l|}{ Sex } \\
\hline Male & $2 / 50$ & $4.0 \%$ & $0.5-13.2$ & $2.381(1)$ & 0.072 \\
\hline Female & $10 / 70$ & $14.3 \%$ & $7.1-24.7$ & & \\
\hline \multicolumn{6}{|l|}{ Age } \\
\hline$<2$ Years & $0 / 29$ & $0.0 \%$ & $0.0-11.9$ & $2.91(1)$ & 0.038 \\
\hline$\geq 2$ Years & $12 / 91$ & $13.2 \%$ & $7-2.9$ & & \\
\hline \multicolumn{6}{|l|}{ Breed } \\
\hline Pure breed & $1 / 11$ & $9.1 \%$ & $0.2-41.3$ & $0(1)$ & 1 \\
\hline Mixed breed & $11 / 109$ & $10.1 \%$ & $5.2-17.3$ & & \\
\hline \multicolumn{6}{|l|}{ Origin } \\
\hline Shelter & $11 / 90$ & $12.2 \%$ & $6.3-20.8$ & $1.111(1)$ & 0.290 \\
\hline Owned & $1 / 30$ & $3.3 \%$ & $0.1-17.2$ & & \\
\hline Total & $12 / 120$ & $10.0 \%$ & $5.3-16.8$ & - & - \\
\hline
\end{tabular}

ClConfidence interval

Table 2 Prevalence of Dirofilaria repens infection in sampled dogs from the Republic of Moldova

\begin{tabular}{llllll}
\hline Variables & Frequency & Prevalence & $95 \% \mathrm{Cl}$ & $x^{2}(d f)$ & $P$-value \\
\hline $\begin{array}{l}\text { Location } \\
\text { Chișinău }\end{array}$ & $6 / 78$ & $7.7 \%$ & $2.9-16.0$ & $0(1)$ & 1 \\
$\begin{array}{c}\text { Cahul } \\
\text { Sex }\end{array}$ & $4 / 42$ & $9.5 \%$ & $2.7-22.6$ & & \\
Male & $2 / 50$ & $4.0 \%$ & $0.5-13.2$ & $1.246(1)$ & 0.19 \\
Female & $8 / 70$ & $11.4 \%$ & $7.1-24.7$ & & \\
Age & & & & & \\
$<2$ Years & $0 / 29$ & $0.0 \%$ & $0.0-12.0$ & $2.186(1)$ & 0.115 \\
$\geq 2$ Years & $10 / 91$ & $11.0 \%$ & $5.2-19.3$ & & \\
Breed & & & & & \\
$\quad$ Pure breed & $1 / 11$ & $9.1 \%$ & $0.2-41.3$ & $0(1)$ & 1 \\
$\quad$ Mixed breed & $9 / 109$ & $8.3 \%$ & $3.9-15.1$ & & \\
Origin & & & & & \\
$\quad$ Shelter & $9 / 90$ & $10.0 \%$ & $4.7-18.1$ & $0.581(1)$ & 0.448 \\
$\quad$ Owned & $1 / 30$ & $3.3 \%$ & $0.1-17.2$ & & \\
Total & $10 / 120$ & $8.3 \%$ & $4.1-14.8$ & - & - \\
\hline
\end{tabular}

difference was not statistically significant. No other significant risk factors were identified (Tables 2, 3).

The molecular analysis confirmed the microscopy outcomes. In the case of Acanthocheilonema spp. infection, the sample was PCR positive for $A$. reconditum, while the BLAST analysis revealed a $100 \%$ nucleotide similarity to an $A$. reconditum sequence from a dog from Italy (GenBank: JF461456). For D. immitis, all five sequences were 
Table 3 Prevalence of Dirofilaria immitis infection in sampled dogs from the Republic of Moldova

\begin{tabular}{llllll}
\hline Variables & Frequency & Prevalence & $95 \% \mathrm{Cl}$ & $x^{2}(d f)$ & $P$-value \\
\hline Location & & & & & \\
$\quad$ Chișinău & $2 / 78$ & $2.6 \%$ & $0.3-9.00$ & $0.516(1)$ & 0.341 \\
$\quad$ Cahul & $3 / 42$ & $7.1 \%$ & $1.5-19.5$ & & \\
Sex & & & & & \\
Male & $2 / 50$ & $4.0 \%$ & $0.5-13.7$ & $0(1)$ & 1 \\
$\quad$ Female & $3 / 70$ & $4.3 \%$ & $0.9-12.0$ & & \\
Age & & & & & \\
$<2$ Years & $0 / 29$ & $0.0 \%$ & $0.0-11.9$ & $0.571(1)$ & 0.334 \\
$\geq 2$ Years & $5 / 91$ & $5.5 \%$ & $1.8-12.4$ & & \\
Breed & & & & & \\
$\quad$ Pure breed & $0 / 11$ & $0.0 \%$ & $0.0-29.5$ & $0(1)$ & 1 \\
$\quad$ Mixed breed & $5 / 109$ & $4.6 \%$ & $1.5-10.4$ & & \\
Origin & & & & & \\
$\quad$ Shelter & $5 / 90$ & $5.6 \%$ & $1.8-12.5$ & $0.626(1)$ & 0.329 \\
$\quad$ Owned & $0 / 30$ & $0.0 \%$ & $0.0-11.6$ & & \\
Total & $5 / 120$ & $4.2 \%$ & $1.4-9.5$ & - & - \\
\hline
\end{tabular}

identical, and had $100 \%$ nucleotide similarity to other isolates from Europe and Asia (e.g. GenBank LC107816, KF692101, MK250715, KR870344). Two different sequences were obtained from the $D$. repens isolates. The first one, identified from nine dogs, was $100 \%$ identical to three other European isolates from human cases (GenBank: KR998257, KX265049) and mosquitoes (GenBank: MF695085). The second sequence, identified from a dog originating in Cahul, was $100 \%$ similar to an isolate from a human case (GenBank: AB973225), a Japanese woman after she had travelled to Europe.

\section{Discussion}

The Republic of Moldova is one of the countries for which few epidemiological data are available on Dirofilaria spp. and A. reconditum. A lack of diagnostic tools, misdiagnosis, and the low awareness of doctors and veterinarians of dirofilariasis are considered to be the main factors responsible for this gap in knowledge [15]. In a molecular study conducted from 2010 to 2015, of 347 pools of female mosquitoes analysed, 92 and 30 tested positive for $D$. repens and $D$. immitis, respectively. From their analysis of the geographic distribution and temperatures of the sites where the positive sample were collected, the authors concluded that the entire country has favourable climatic conditions for the transmission of Dirofilaria spp. [15]. The results of our study are in line with this conclusion. Only one previous study has reported the presence of $D$. immitis in canine populations in the Republic of Moldova. A total of 13 shepherd dogs originating from two counties, Ialoveni and Criuleni, located in the central part of Moldova, were evaluated for the presence of various parasite species by necropsy, and three of the examined dogs were found to be infected with $D$. immitis [18]. The method used to identify the parasites was not given, and it was also unclear if the positive dogs originated from the same county. Although both $D$. immitis and D. repens have been found in the human population of the Republic of Moldova, most of the available information comprises individual case reports, where the nematodes were identified based on microscopic examination only. Five cases of human dirofilariasis were reported up until 2016 [15]. However, it is not clear if these cases were autochthonous or imported [15]. An extensive study on the human population of the Republic of Moldova was performed in 2018, when 263 serum samples were screened for exposure of individuals to Dirofilaria spp. One sample was positive for $D$. repens antigens, 36 were positive for anti-D. immitis immunoglobulin G, and three samples were reactive for antigens of both D. immitis and D. repens [14].

Although previous studies found that sex [19] or breed [20] are risk factors for Dirofilaria spp. infection in dogs, our study found no significant differences regarding location, sex, breed or origin of the animals. This might be due to the low numbers of samples used. However, prevalence of infection was significantly higher for dogs aged $\geq 2$ years. Age was previously highlighted as one of the most important risk factors for infection [20, 21]. Our study included two categories of dogs: those that were owned, and those that lived in a shelter. Considering that, to our knowledge, none of the dogs, regardless of their origin, had received prophylactic treatment for dirofilariasis, we can assume that the difference in prevalence between the two categories, although not statistically significant, was related to the length of time that they spent outside, and consequently, their potential exposure to the vectors.

Infections with $D$. repens and $A$. reconditum have not been previously reported for the Republic of Moldova. However, in Ukraine, which borders the Republic of Moldova to the east, north and south, and Romania, the western neighbour state, many infections with these pathogens have been reported in human and animal populations. In Ukraine, dirofilariasis caused by $D$. repens was first reported in dogs in 1904 and in humans in 1927 [22]. Between 1997 and 2013, a total of 1465 cases of infection with $D$. repens were confirmed in humans. The incidence of Dirofilaria infection ranged between $0.07-3.71$ per 100,000 people in the geographical areas neighbouring the Republic of Moldova. Due to the presence of the pathogen in all the oblasts of Ukraine, as well as the high incidence registered in many regions, the authors concluded that dirofilariasis due to D. repens 
is an emergent zoonosis in the country [22]. Rossi et al. [23] demonstrated the implication of both $D$. immitis and $D$. repens in ocular and subcutaneous pathologies in humans in Ukraine. In Romania, sporadic infections with D. immitis in dogs had been reported from the beginning of the twentieth century, but more recent studies, which used various diagnostic methods, revealed prevalences ranging from $23.1 \%$ to $38.0 \%$ [24, 25]. In 2014, both $D$. immitis and $D$. repens were categorized as endemic in areas of southern and southeastern Romania, and the same study provided the first extensive overview of the prevalence and distribution of $A$. reconditum in the country [26]. Taking into consideration the epidemiological situation in Europe, and in particular in the two neighbouring countries of the Republic of MoldovaRomania and Ukraine - as well as the favourable climatic conditions for the transmission of Dirofilaria spp. in the former, it is highly probable that the limited number of reports of these pathogens in the Republic of Moldova is the result of a lack of targeted epidemiological studies.

During the last decades, infections with Dirofilaria spp. in dogs have spread from the traditionally endemic regions of Italy, Spain, France, [27] into central, eastern and northeastern European countries such as Switzerland [10], Germany [28], Austria [29], Czech Republic [30], Poland [31] and Romania [25]. Interestingly, though, a new trend in the distribution of these pathogens has recently been observed: the prevalence of dirofilariasis has decreased in the last few years in western Europe in areas of high endemicity. This has been attributed to increased awareness of these diseases and, as a consequence, greater acceptance and widespread use of preventative measures [32]. In contrast, in non-endemic regions, or where these parasites have not been previously reported (including eastern European countries), recent data have shown first cases and/or an increase in the prevalence of these helminth infections. The spread of these pathogens is likely facilitated by climate change, the lack of experience of veterinary practitioners in diagnosing and treating infections with them, poor awareness of these diseases amongst both medical personnel and dog owners, and a high number of stray dogs [32]. Austria, which reported the presence of autochthonous D. repens for the first time in 2012 [33], announced that infections with $D$. immitis and $D$. repens had tripled by 2018 [34]. Similar epidemiological patterns have been reported for Romania and Ukraine [22, 35].

Many methods have been proposed for the diagnosis of filarioid infections in dogs. However, a lack of sensitivity of microscopic methods for the detection of larvae, crossreactivity with Angiostrongylus vasorum of some commercially available antigen tests for $D$. immitis, and false negative results found with the same type of test where the parasitic burden is low, are the main limitations of these diagnostic tools $[4,23]$. PCR, duplex real-time PCR and multiplex PCR are considered useful diagnostic tools for both epidemiological and clinical studies [4]. Our study presents the results of epidemiological screening using two types of complementary tests, i.e. microscopic and molecular, that should strengthen the reliability of the presented data.

Dogs are the main reservoirs of Dirofilaria spp., and thus serve as a source of infection for mosquito vectors and possible subsequent transmission to humans and other susceptible mammalian hosts [5]. Monitoring the canine population is an important step for the design of prevention programmes aimed to decrease the risk of zoonoses caused by Dirofilaria spp. The need for more detailed information and the development of monitoring programmes and epidemiological studies on dirofilariasis and other zoonotic vector-borne pathogens in dogs from the Republic of Moldova has been previously highlighted $[14,15]$. More data on the prevalence and geographical distribution of Dirofilaria spp. in dogs, humans and vectors would allow a better understanding of the circulation of these pathogens in the Republic of Moldova. Although we recognize that the sample size used here is not high, the results of our study should raise awareness amongst veterinarians and physicians. The circulation of dogs between different countries, with their owners or for commercial reasons, is becoming increasingly common. In light of the current study, dogs originating from the Republic of Moldova should be screened for Dirofilaria spp. and Acanthocheilonema spp. Moreover, preventive measures are advisable for dogs (and their owners) entering the Republic of Moldova.

The role of stray dogs in the circulation of these filarial worms, and thus the high risk that they pose for human health, has been previously demonstrated [36]. Although origin was not identified as a risk factor in our study, possibly due to the small sample size, we believe that stray dogs could act as an important source of infection with filarial worms in other carnivores and in humans. The responsible authorities and institutions should increase their efforts to decrease the stray dog population, and to control and apply preventative measures to limit the spread of dirofilariasis. To the best of our knowledge, our findings on $A$. reconditum and $D$. repens represent the first report of these pathogens in the canine population of the Republic of Moldova.

\section{Conclusions}

The present epidemiological survey confirms the presence in the Republic of Moldova of D. immitis, $D$. repens and $A$. reconditum in dogs that did not receive any heartworm preventive. The data reported here 
extend our knowledge of the geographical distribution of these nematodes and highlight the need for the development of programmes to prevent their spread because of the deleterious effects that they can have on animal and human health.

\section{Abbreviations}

BLAST: Basic Local Alignment Search Tool; bp: Base pair; Cl: Confidence interval; PCR: Polymerase chain reaction

\section{Acknowledgements}

Not applicable.

\section{Authors' contributions}

MOD: conceptualization, funding acquisition, investigation, writing —original draft, formal analysis, methodology, project administration. GD: investigation, writing - review and editing. EV: investigation. SM: investigation. VM: methodology, writing - review and editing. AMl: writing_original draft, writing review and editing, formal analysis, data curation. All authors have read and approved the final manuscript.

\section{Funding}

This study was supported by the CNCS-UEFISCDI Grant Agency Romania (grant number PD38/2018).

\section{Availability of data and materials}

Some of the datasets generated, used and analysed during the current study are included in this published article and some of the data are available from the corresponding author on reasonable request. The four sequences generated herein were deposited in GenBank under accession numbers MW656248-MW656251.

\section{Declarations}

\section{Ethics approval and consent to participate}

This study (project number: PD38/2018) was approved by the Ethical Committee of the University of Agricultural Sciences and Veterinary Medicine Cluj-Napoca, Cluj, Romania. Informed consent was obtained from the owner or manager of the shelter before a dog's inclusion in the study.

\section{Consent for publication}

Not applicable.

\section{Competing interests}

The authors declare that they have no competing interests.

\section{Author details}

${ }^{1}$ Department of Parasitology and Parasitic Diseases, University of Agricultural Sciences and Veterinary Medicine Cluj-Napoca, 3-5 Mănăştur Street, 400372 Cluj-Napoca, Romania. ${ }^{2}$ Faculty of Veterinary Medicine, State Agrarian University of Moldova, 48 Mircești Street, Chişinău, Republic of Moldova. ${ }^{3}$ CDS-9, "Regele Mihai I Al României" Life Science Institute, University of Agricultural Sciences and Veterinary Medicine Cluj-Napoca, 3-5 Mănăştur Street, 400372 Cluj-Napoca, Romania. ${ }^{4}$ Agenția Națională pentru Siguranța Alimentelor, MD3900 str. Griviței, 28, Cahul, Republic of Moldova.

Received: 6 May 2021 Accepted: 23 July 2021

Published online: 06 August 2021

\section{References}

1. Dantas-Torres F, Otranto D. Overview on Dirofilaria immitis in the Americas, with notes on other filarial worms infecting dogs. Vet Parasitol. 2020;282:109113.
2. Egyed Z, Sréter T, Széll Z, Beszteri B, Oravecz O, Márialigeti K, et al. Morphologic and genetic characterization of Onchocerca lupi infecting dogs. Vet Parasitol. 2001:102:309-19.

3. Otranto D, Brianti E, Dantas-Torres F, Weigl S, Latrofa MS, Gaglio G, et al. Morphological and molecular data on the dermal microfilariae of a species of Cercopithifilaria from a dog in Sicily. Vet Parasitol. 2011;182:221-9.

4. Otranto D, Dantas-Torres F, Brianti E, Traversa D, Petrić D, Genchi C, et al. Vector-borne helminths of dogs and humans in Europe. Parasit Vectors. 2013;6:16.

5. Simón F, Siles-Lucas M, Morchón R, González-Miguel J, Mellado I, Carretón E, et al. Human and animal dirofilariasis: the emergence of a zoonotic mosaic. Clin Microbiol Rev. 2012;25:507-44.

6. Latrofa MS, Montarsi F, Ciocchetta S, Annoscia G, Dantas-Torres F, Ravagnan S, et al. Molecular xenomonitoring of Dirofilaria immitis and Dirofilaria repens in mosquitoes from north-eastern Italy by real-time PCR coupled with melting curve analysis. Parasit Vectors. 2012;5:76.

7. Simón F, López-Belmonte J, Marcos-Atxutegi C, Morchón R, Martín-Pacho J. What is happening outside North America regarding human dirofilariasis? Vet Parasitol. 2005;133:181-9.

8. Morchón R, Carretón E, González Miguel J, Mellado HI. Heartworm disease (Dirofilaria immitis) and their vectors in Europe — new distribution trends. Front Physiol. 2012;3:196.

9. Pupić-Bakrač A, Pupić-Bakrač J, Jurković D, Capar M, Stefanović LL, Ćelović $I A$, et al. The trends of human dirofilariasis in Croatia: yesterday-todaytomorrow. One Health. 2020;10:100153.

10. Capelli G, Genchi C, Baneth G, Bourdeau P, Brianti E, Cardoso L, et al. Recent advances on Dirofilaria repens in dogs and humans in Europe. Parasit Vectors. 2018;11:663.

11. Huynh T, Thean J, Maini R. Dipetalonema reconditum in the human eye. $\mathrm{Br}$ J Ophthalmol. 2001;85:1384.

12. Brianti E, Gaglio G, Napoli E, Giannetto S, Dantas-Torres F, Bain O, et al. New insights into the ecology and biology of Acanthocheilonema reconditum (Grassi, 1889) causing canine subcutaneous filariosis. Parasitology. 2012;139:530-6.

13. Laidoudi Y, Davoust B, Varloud M, Fenollar F, Mediannikov O. Development of a multiplex qPCR-based approach for the diagnosis of Dirofilaria immitis, D. repens and Acanthocheilonema reconditum. Parasit Vectors. 2020;13:319.

14. Ciuca L, Simòn F, Rinaldi L, Kramer L, Genchi M, Cringoli G, et al. Seroepidemiological survey of human exposure to Dirofilaria spp. in Romania and Moldova. Acta Trop. 2018;187:169-74.

15. Sulesco T, Von Thien H, Toderaş L, Toderaş I, Lühken R, Tannich E. Circulation of Dirofilaria repens and Dirofilaria immitis in Moldova. Parasit Vectors. 2016;9:627.

16. Magnis J, Lorentz S, Guardone L, Grimm F, Magi M, Naucke TJ, et al. Morphometric analyses of canine blood microfilariae isolated by the Knott's test enables Dirofilaria immitis and D. repens species-specific and Acanthocheilonema (syn. Dipetalonema) genus-specific diagnosis. Parasit Vectors. 2013;6:48.

17. Latrofa MS, Weigl S, Dantas-Torres F, Annoscia G, Traversa D, Brianti E, et al. A multiplex PCR for the simultaneous detection of species of filarioids infesting dogs. Acta Trop. 2012;122:150-4.

18. Dumitriu A. Răspîndirea helmintozelor la Canis familiaris în unele gospodării particulare de ovine. In: Cimpoies G, Marian G, Donica G, editors Agricultura modernă—realizări şi perspective Chisinau: Universitatea Agrară de Stat din Moldova, Medicină Veterinară; 182-4.

19. Savić S, Stosic MZ, Marcic D, Hernández I, Potkonjak A, Otasevic S, et al. Seroepidemiological study of canine and human dirofilariasis in the endemic region of northern Serbia. Front Vet Sci. 2020;7:571.

20. Vieira AL, Vieira MJ, Oliveira JM, Simões AR, Diez-Baños P, Gestal J. Prevalence of canine heartworm (Dirofilaria immitis) disease in dogs of Central Portugal. Parasite. 2014;21:5.

21. Diakou A, Kapantaidakis E, Tamvakis A, Giannakis V, Strus N. Dirofilaria infections in dogs in different areas of Greece. Parasit Vectors. 2016;9:508.

22. Sałamatin R, Pavlikovska T, Sagach O, Nikolayenko S, Kornyushin V, Kharchenko V, et al. Human dirofilariasis due to Dirofilaria repens in Ukraine, an emergent zoonosis: epidemiological report of 1465 cases. Acta Parasitol. 2013;58:592-8.

23. Rossi A, Peix Á, Pavlikovskaya T, Sagach O, Nikolaenko S, Chizh N, et al. Genetic diversity of Dirofilaria spp. isolated from subcutaneous and ocular lesions of human patients in Ukraine. Acta Trop. 2015;142:1-4. 
24. Coman S, Bacescu B, Coman T. Epidemiological and paraclinical aspects in dirofilariosis in dogs. Proceedings of the First European Dirofilaria Days, Zagreb, Croatia, 2007.

25. Mircean V, Dumitrache MO, Györke A, Pantchev N, Jodies R, Mihalca AD, et al. Seroprevalence and geographic distribution of Dirofilaria immitis and tick-borne infections (Anaplasma phagocytophilum, Borrelia burgdorferi sensu lato, and Ehrlichia canis) in dogs from Romania. Vector Borne Zoonotic Dis. 2012;12:595-604.

26. Ionică AM, Matei IA, Mircean V, Dumitrache MO, D'Amico G, Győrke A, et al. Current surveys on the prevalence and distribution of Dirofilaria spp. and Acanthocheilonema reconditum infections in dogs in Romania. Parasitol Res. 2015;114:975-82.

27. Genchi C, Bowman D, Drake J. Canine heartworm disease (Dirofilaria immitis) in Western Europe: survey of veterinary awareness and perceptions. Parasit Vectors. 2014;7:206.

28. Kronefeld M, Kampen H, Sassnau R, Werner D. Molecular detection of Dirofilaria immitis, Dirofilaria repens and Setaria tundra in mosquitoes from Germany. Parasit Vectors. 2014;7:30.

29. Fuehrer H-P, Auer H, Leschnik M, Silbermayr K, Duscher G, Joachim A. Dirofilaria in humans, dogs, and vectors in Austria (1978-2014)_from imported pathogens to the endemicity of Dirofilaria repens. PLoS Negl Trop Dis. 2016;10:e0004547.

30. Svobodová Z, Svobodová V, Genchi C, Forejtek P. The first report of authochthonous dirofilariosis in dogs in the Czech Republic. Helminthologia. 2006;43:242-5.
31. Świątalska A, Demiaszkiewicz AW. Pierwszy w Polsce rodzimy przypadek inwazji nicieni Dirofilaria immitis u psa. Życie Weterynaryjne. 2012;87:685-6.

32. Genchi C, Kramer LH. The prevalence of Dirofilaria immitis and D. repens in the Old World. Vet Parasitol. 2020;280:108995.

33. Silbermayr K, Eigner B, Joachim A, Duscher GG, Seidel B, Allerberger $F$, et al. Autochthonous Dirofilaria repens in Austria. Parasit Vectors. $2014 ; 7: 226$

34. Sonnberger K, Duscher GG, Fuehrer H-P, Leschnik M. Current trends in canine dirofilariosis in Austria-do we face a pre-endemic status? Parasitol Res. 2020;119:1001-9.

35. Tomazatos A, Cadar D, Török E, Maranda I, Horváth C, Keresztes L, et al. Circulation of Dirofilaria immitis and Dirofilaria repens in the Danube Delta Biosphere Reserve Romania. Parasit Vectors. 2018;11:392.

36. Stoyanova H, Carretón E, Montoya-Alonso JA. Stray dogs of Sofia (Bulgaria) could be an important reservoir of heartworm (Dirofilaria Immitis). Helminthologia. 2019;56:329.

\section{Publisher's Note}

Springer Nature remains neutral with regard to jurisdictional claims in published maps and institutional affiliations.
Ready to submit your research? Choose BMC and benefit from:

- fast, convenient online submission

- thorough peer review by experienced researchers in your field

- rapid publication on acceptance

- support for research data, including large and complex data types

- gold Open Access which fosters wider collaboration and increased citations

- maximum visibility for your research: over 100M website views per year

At BMC, research is always in progress.

Learn more biomedcentral.com/submissions 